\title{
The True Cost of Renewables:
}

An Analytic Response to the Coal Industry's Attack on Renewable Energy

\author{
Blair G. Swezey and Yih-huei Wan
}

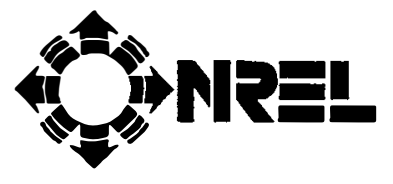

National Renewable Energy Laboratory 1617 Cole Boulevard Golden, Colorado 80401-3393

A national laboratory of the U.S. Department of Energy Managed by Midwest Research Institute under Contract No. DE-AC36-83CH10093

Prepared under Task No. AS819409

October 1995 


\section{NOTICE}

This report was prepared as an account of work sponsored by an agency of the United States government. Neither the United States government nor any agency thereof, nor any of their employees, makes any warranty, express or implied, or assumes any legal liability or responsibility for the accuracy, completeness, or usefulness of any information, apparatus, product, or process disclosed, or represents that its use would not infringe privately owned rights. Reference herein to any specific commercial product, process, or service by trade name, trademark, manufacturer, or otherwise does not necessarily constitute or imply s endorsement, recommendation, or favoring by the United States government or any agency thereof. The views and opinions of authors expressed herein do not necessarily state or reflect those of the United States government or any agency thereof.

Available to DOE and DOE contractors from: Office of Scientific and Technical Information (OSTI)

P.O. Box 62

Oak Ridge, TN 37831

Prices available by calling (615) $576-8401$

Available to the public from:

National Technical Information Service (NTIS)

U.S. Department of Commerce

5285 Port Royal Road

Springfield, VA 22161

(703) $487-4650$ 
One intended result of federal investments in renewable energy research and development (R\&D) programs is the adoption and use of renewable energy technologies in the energy marketplace. Insights into the nature of energy markets can help to assure that the technologies being developed are compatible with these markets.

In April 1995, the Center for Energy and Economic Development (CEED), a coal industry lobbying group, issued a report critical of the role that renewable energy technologies can play in future power sector markets. Both the National Renewable Energy Laboratory (NREL) and the U.S. Department of Energy (DOE) felt that it was important to respond to the CEED report by examining its basic assumptions regarding renewable energy and fossil-fuel-based technologies and future power markets. This report documents the NREL analysis that refutes many of the CEED report's key findings.

NREL's Analytic Studies Division (ASD) supports the long-range planning of the overall federal renewable energy $R \& D$ program, both at NREL and DOE, by conducting analyses on aspects of energy market competition that are relevant to the present and future deployment of renewable energy technologies. ASD reports on these efforts to DOE and NREL managers, as well as external utility sector stakeholders, to enhance their awareness of competitive and institutional factors that may affect the successful deployment of renewable energy technologies in the marketplace.

The authors wish to acknowledge the support of the Office of Utility Technologies in the Office of Energy Efficiency and Renewable Energy at DOE and to thank several external reviewers. The authors also thank Mary Anne Dunlap for editorial assistance.

Approved for the

NATIONAL RENEWABLE ENERGY LABORATORY

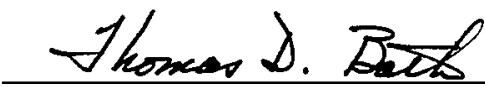

Thomas D. Bath, Director

Analytic Studies Division

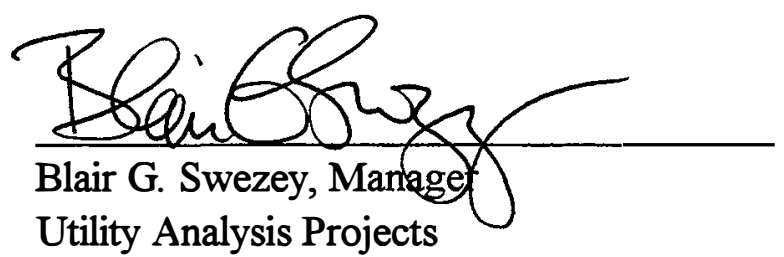




\section{Contents}

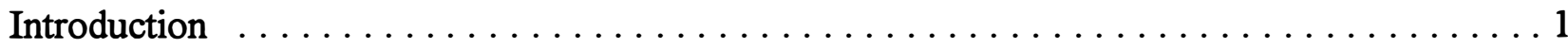

The True Cost of Renewables $\ldots \ldots \ldots \ldots \ldots \ldots \ldots \ldots \ldots \ldots \ldots \ldots \ldots \ldots$

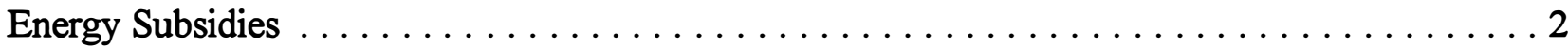

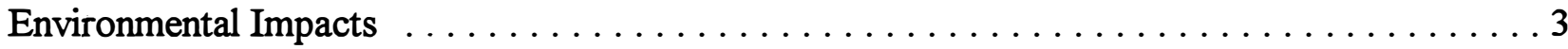

The Reliability of Renewable Energy Systems $\ldots \ldots \ldots \ldots \ldots \ldots \ldots \ldots \ldots \ldots$

The Impact of Electricity Competition $\ldots \ldots \ldots \ldots \ldots \ldots \ldots \ldots \ldots \ldots \ldots \ldots \ldots \ldots \ldots \ldots$

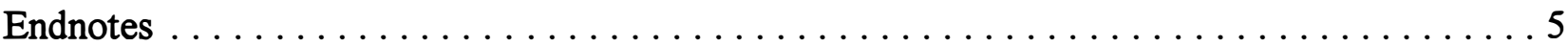

Appendix: NREL Calculation of National Renewable Energy Deployment Costs $\ldots \ldots \ldots \ldots$

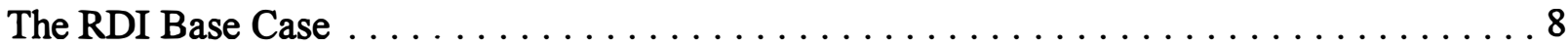

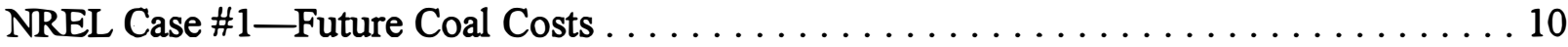

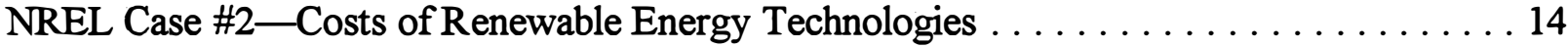

NREL Case \#3-Market Penetration of Renewable Energy Technologies $\ldots \ldots \ldots \ldots$

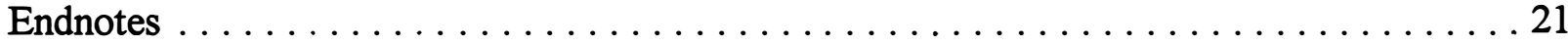




\section{Introduction}

In April 1995, the Center for Energy and Economic Development (CEED), an umbrella organization of pro-coal interests, released a report entitled Energy Choices in a Competitive Era: The Role of Renewable and Traditional Energy Resources in America's Electric . . . a modest growth path of renewable resource development would essentially cost the nation little more than projected electricity market costs for coal-fired generation. ...

Generation Mix. The report purports to show that a very modest growth in the use of renewable energy in the U.S. power sector would entail unaffordable costs for the nation's electricity ratepayers.

The National Renewable Energy Laboratory (NREL) was commissioned by the U.S. Department of Energy (DOE) to review the assumptions contained in the report, which was prepared for CEED by Resource Data International, Inc. (RDI). The NREL analysis finds that the conclusions of the CEED/RDI study are based on faulty data and assumptions regarding the comparative economics of coal and renewable energy development. After correcting these errors, NREL finds that a modest growth path of renewable resource development would essentially cost the nation little more than projected electricity market costs for coal-fired generation, even before considering the environmental benefits that would accompany this development.

\section{The True Cost of Renewables}

The CEED/RDI study claims that a modest increase in the contribution of nonhydro renewable energy sources, from $2 \%$ of total electricity supply today to $4 \%$ in 2010 , will cost the nation $\$ 52$ billion "above today's most competitive power alternatives." NREL estimates that the extra cost of renewables development would be $\$ 1.9$ billion over 15

.. because renewable energy technologies will become more, not less, cost competitive, nonhydro renewables could . . supply a much larger fraction of the future power market than the $4 \%$ assumed by CEED/RDI. years, or an average of just more than $\$ 100$ million annually — less than one-tenth of $1 \%$ of the total annual revenue of the U.S. electric utility industry. In fact, the NREL analysis shows that certain renewable energy technologies, such as geothermal and wind, are projected to become more economic than coal during this period.

Why the big difference? First, the CEED/RDI analysis relies on data that overstate the cost and performance advantages of coal-fired plants. The NREL analysis used coal data from the Electric Power Research Institute (EPRI), the national research and development (R\&D) organization for the electric utility industry, and from the U.S. Energy Information Administration (EIA), the statistical arm of DOE. This change alone reduces the CEED/RDI renewables cost by $\$ 8.6$ billion. 
Second, the CEED/RDI analysis employs unjustifiably high cost estimates for renewable energy technologies and assumes no improvement in technology costs and performance throughout the 15year analysis period. This assumption is contrary to recent market experience, which has seen several utilities contract for cost-effective renewable energy power. In addition, this assumption runs counter to the last 15 years of history, which has witnessed dramatic improvement in renewable energy technology costs and performance. Many energy analysts expect these improvements to continue. ${ }^{1}$ For its analysis, NREL substituted renewable energy cost data from DOE, which are more representative of current market costs and which account for expected future technology improvements. This substitution accounts for a further reduction of $\$ 31.6$ billion from the CEED/RDI estimate.

Finally, the CEED/RDI analysis assumes a fixed market share for renewable energy technologies. It does not consider comparative economics or the ability of renewable energy industries to supply the market. The NREL analysis assumes a more orderly development path for the renewables industries. This final difference reduces the CEED/RDI estimate by another $\$ 9.9$ billion, leaving a total "above-market" cost estimate of only $\$ 1.9$ billion over the next 15 years. Furthermore, because renewable energy technologies will become more, not less, cost competitive, nonhydro renewables could be reasonably expected to supply a much larger fraction of the future power market than the $4 \%$ assumed by CEED/RDI.

\section{Energy Subsidies}

The CEED/RDI study implies that renewable energy technologies can only be competitive with massive public subsidies, stating that "advocates for renewable energy technologies are increasingly heading to public policy forums as they fail to make their case in the open market" (page 16). "because the great bulk of incentives support mature fossil fuel and nuclear equipment, the existing subsidy structure markedly distorts the marketplace ... away from renewables." - Congressional Research Service

However, what CEED/RDI fail to note is that coal and other fossil fuels historically have been and continue to be the recipients of massive public subsidies. A recent paper by the Congressional Research Service (CRS) summarizes the findings of several energy subsidy studies, including a 1992 study by DOE's EIA. ${ }^{2}$ These studies have consistently found that public subsidies given to fossil fuels far outweigh incentives available for renewables development. Indeed, CRS notes that the most recent of these analyses found that "because the great bulk of incentives support mature fossil and nuclear equipment, the existing subsidy structure markedly distorts the marketplace for energy in a direction away from renewables."

Most recently, the federal government has contributed nearly $\$ 3$ billion to the development of new coal-buming technologies through the Clean Coal Technology Program, while the renewable energy industry is today fighting to maintain a $\$ 300$ million annual federal $R \& D$ budget for all renewable 
energy technologies combined. ${ }^{3}$ And RDI itself, in another recent analysis, estimates that ratepayers nationwide will incur costs of $\$ 14.8$ billion because of above-market, long-term coal contracts between electric utilities and coal producers. ${ }^{4}$

\section{Environmental Impacts}

While CEED/RDI expend great effort to ascribe negative environmental impacts to renewables, they conveniently ignore the costly environmental impacts associated with the combustion of fossil fuels. For example, because of fossil-fuel-based emissions of sulfur dioxide and nitrogen oxides, electricity ratepayers will be The prospective environmental cleanup costs of fossil-fuel-based plants are never considered up front when generation investment decisions are made. ...

required to pay $\$ 4$ billion or more per year to clean up emissions under the Clean Air Act Amendments of 1990. ${ }^{5}$ The specter of additional emissions control requirements (e.g., for control of air toxics and fine particulates, not to mention carbon dioxide), as well as environmental taxes, potentially creates additional cost burdens.

The prospective environmental cleanup costs of fossil-fuel-based plants are never considered up front when generation investment decisions are made; only later are ratepayers presented with these costs.

\section{The Reliability of Renewable Energy Systems}

To further discredit renewables, the CEED/RDI report states that many renewable energy systems are inherently unreliable. In fact, using traditional utility reliability criteria as a gauge, the reliability of renewables projects is generally comparable to that of conventional utility generating plants. For example, the availability of newer wind plants has improved to $95 \%$ or greater on average. ${ }^{6}$ And photovoltaics systems are highly valued in remote applications specifically for their high reliability compared with the reliability of diesel generation and stand-alone battery systems.

CEED/RDI point to the capacity factors and dispatchability of renewable projects as reliability issues. However, the majority of renewable technologies can operate in base load or are otherwise dispatchable; geothermal units can have capacity factors greater than $90 \%$. For comparison, the average capacity factor for all operating coal-fired power plants in the United States was $60 \%$ from 1990 to 1994 . $^{7}$ Solar- and wind-based projects, without storage, typically have capacity factors of $20 \%$ to $30 \%$ because they operate only when the sun shines or the wind blows.

However, the plant capacity factor is not as important as whether the plant generates its predicted output, that is, the output level upon which the economic decision to build the plant was based. 
Also, utility plants are dispatched based on production costs, and because many renewables have low production costs, renewables tend to be dispatched whenever the output is available to displace the power produced from units with higher production costs.

When power from intermittent resources is not available, other generators on the system must be called upon to supply the power. At low penetration levels, this situation is much like the normal utility system response to load fluctuations. At higher penetration levels, a utility might have to provide additional dispatchable capacity to compensate for both normal load fluctuations and the output variations of intermittent generators. A recent NREL review of this topic suggests that intermittent generation levels of at least $10 \%$ can be accommodated with no adverse system impacts. ${ }^{8}$ Already today, wind generation provides up to $7 \%$ of the system load, and has supplied about $5 \%$ during peak hours, on the Pacific Gas and Electric system with no adverse effects. ${ }^{9}$ These intermittent penetration levels are far above the contributions examined in the CEED/RDI study. In fact, research shows that intermittent penetration levels above $10 \%$ are also entirely feasible, with any technical limits being a function of the specific utility system characteristics. ${ }^{10}$

\section{The Impact of Electricity Competition}

Finally, CEED and RDI state that with "open and direct competition" in electricity markets, renewable energy use is likely to decline because it will be priced out of the market. On the contrary, the renewable energy industry welcomes truly open and fair competition as a boon to renewables development. ${ }^{11}$ This is because true competition will provide electricity customers with the ability to choose from an expanded number of electricity suppliers offering alternative services, ones that will include renewables. This situation is akin to shopping at a supermarket where customers base their purchases, in part, on product differentiation and perceived value. A large segment of the American public has consistently supported greater development of renewable energy sources, and utility surveys are also revealing customer preferences for renewables. ${ }^{12}$ At the same time, a growing market will ensure continued improvement in the economics of renewable energy technologies.

However, the electric industry is just now beginning its experiment with more competitive market structures. In addition, the existing system of energy subsidies will continue to distort energy market decisions. To the extent that truly fair and competitive markets cannot be obtained, public policies and regulation may still be required to assure that the public interest is factored into market outcomes. And even in a perfectly competitive market, market failures, such as accounting for the uncosted environmental impacts of different energy resources and assuring adequate provision of public goods, will continue to exist. A properly functioning competitive market should provide ample development opportunities for renewables. We won't really know until effective market tests are performed. 


\section{Endnotes}

1. See, for example, the discussion on renewable energy in DOE's recent National Energy Policy Plan, which notes that "During the last 15 years, intensive work by industry and the Department of Energy's national laboratories has steadily increased the reliability of renewables energy systems while dramatically lowering their costs. These systems are gradually becoming commercially competitive with conventional power sources" (Sustainable Energy Strategy: Clean and Secure Energy for a Competitive Economy, July 1995, page 44). An analysis of energy futures performed by Shell International notes that renewables costs will continue to fall as production increases. Thus, the key question for renewables is not whether costs will be lowered but "the speed at which market opportunities will appear, to enable renewables to move down their cost curves" (E.J. Grunwald, "Energy in the Long Term," Shell International Petroleum Co. Ltd, undated). And even the CEED/RDI report acknowledges that "renewable energy has made important advances in lowering costs" (page 2-5).

2. F. Sissine, "Renewable Energy: A New National Commitment?" Congressional Research Service, January 5, 1995.

3. U.S. General Accounting Office, Ways to Strengthen Controls Over Clean Coal Technology Project Costs, GAO/RCED-93-104, March 1993.

4. Presentation by Thomas Feiler, RDI, to the National Association of Regulatory Utility Commissioners, July 25, 1995.

5. M. Hoske, "Phase I Compliance Plans Emphasize Flexibility," Electric Light \& Power, August 1993.

6. C. Weinberg, "Wind Energy and the Electric Utility Industry," Proceedings of Windpower '90, American Wind Energy Association, 1990.

7. North American Electric Reliability Council, Generating Unit Statistics 1990-1994, June 1995.

8. Y. Wan and B. Parsons, Factors Relevant to Utility Integration of Intermittent Renewable Technologies, National Renewable Energy Laboratory, NREL/TP-463-4953, August 1993.

9. D. Smith and M. Ilyin, "Wind Energy Evaluation by PG\&E," Proceedings of the Ninth ASME Wind Energy Symposium, 1990.

10. Wan and Parsons, Op Cit.

11. Edwin Mansfield, in his classic microeconomics textbook (Microeconomics: Theory and Applications, Third Edition, W.W. Norton and Company), describes the four conditions that define the model of a perfectly competitive market:

(1) The product of any one seller must be the same as the product of any other seller;

(2) Each participant in the market, whether buyer or seller, must be so small, in relation to 
the entire market, that it cannot by itself affect the market price of the product; (3) All resources must be completely mobile; each resource must be able to enter and leave the market, and switch from one use to another, very readily; and

(4) Consumers, firms, and resource owners must have perfect knowledge of the relevant economic and technological data.

12. See, for example, B. Farhar, Trends in Public Perceptions and Preferences on Energy and Environmental Policy, National Renewable Energy Laboratory, NREL/TP-461-4857, February 1993 and D. Moskovitz, "Green Pricing': Customer Choice Moves Beyond IRP," The Electricity Journal, October 1993. 


\section{Appendix}

\section{NREL Calculation of National Renewable Energy Deployment Costs}

This appendix documents the key assumptions adopted in recalculating the costs of continued renewables deployment as presented in the CEED/RDI report. These assumptions deal with the cost and performance attributes of coal-fired and renewable-energy-based generation, as well as the rate at which different renewable energy technologies penetrate the electricity supply market. 


\section{The RDI Base Case}

To arrive at the $\$ 52$ billion cost estimate for its base case renewables deployment, RDI calculates the difference between the levelized generation cost for a pulverized coal-fired plant, considered to be the lowest-cost generation option, and the weighted average cost of a mix of nonhydro renewables technologies. The renewables technologies are differentiated by those that involve combustion processes (biomass and waste to energy [WTE]) and those that are "naturally occurring" (geothermal, photovoltaics, solar thermal, and wind). RDI assumes that nonhydro renewable energy generation will grow from 75 billion $\mathrm{kWh}$ in 1995 to 180 billion $\mathrm{kWh}$ in 2010 or from $2.32 \%$ to $4.49 \%$ of the total U.S. electricity generation by 2010 . The annual increase in renewable energy generation, for both combustion and noncombustion sources, is multiplied by the RDI-calculated cost differential to obtain an annual cost difference. The sum of these annual cost differences yields the aggregate $\$ 52$ billion cost estimate (Table 1 ).

Although the CEED/RDI report states that the base case levelized cost for a new coal plant is $3.8 \mathrm{c} / \mathrm{kWh}$ (e.g., Table 4-1 on page 4-4), RDI assumes a levelized coal generation cost of $4.20 \mathrm{c} / \mathrm{kWh}$ for the base case calculation in its spreadsheet model (available from CEED). NREL was able to replicate the RDI results using this higher value. 


\section{Table 1. RDI Base Case Scenario}

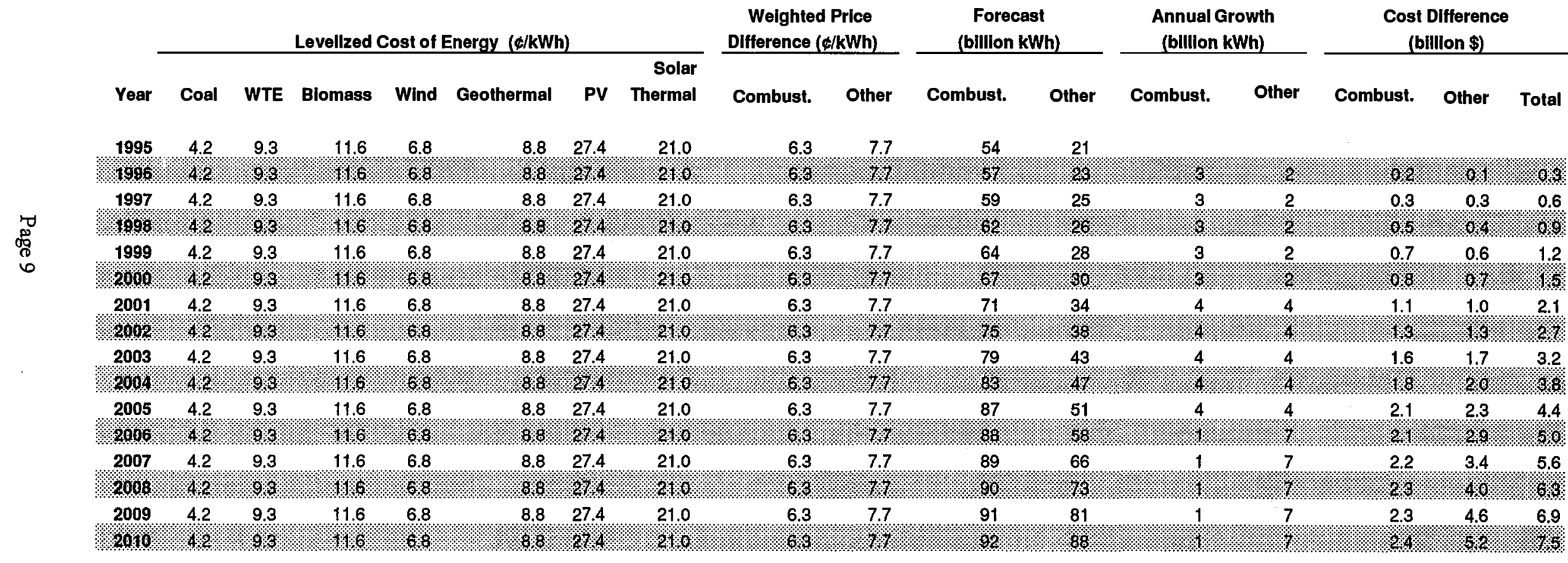

Total 


\section{NREL Case \#1 — Future Coal Costs}

The first sensitivity that NREL examined was the very favorable assumptions that RDI adopted for future coal generation costs. These assumptions fall into three main categories: (1) the capital cost of a new coal-fired plant, (2) the price of coal, and (3) the capacity factor of the plant.

\section{Coal Plant Capital Cost}

RDI assumes a capital cost of $\$ 956 / \mathrm{kW}$ for a new $400-\mathrm{MW}$ coal-fired power plant to be constructed in the Northeast that incorporates a wet flue-gas desulfurization (FGD) system for emissions control. RDI attributes this cost estimate to Duke/Flour Daniel. However, this cost estimate is $20 \%$ below the cost of a new coal-fired plant adopted by the Electric Power Research Institute (EPRI) in its Technical Assessment Guide (TAG). ${ }^{1}$ The EPRI TAG is a standardized utility industry primer that provides generic technology cost and performance data that utilities can use to perform preliminary screening analyses of resource options. Although the TAG may be useful for ranking different technology options for planning purposes, the cost data do not necessarily reflect the actual utility cost of installing a power plant today. However, no new utility-owned, coal-fired capacity has been brought into service since 1992 from which current market cost data can be derived. Data for 1991 from RDI's own POWERdat database yields a cost range of from $\$ 705 / \mathrm{kW}$ for a 705.5 -MW addition to a pre-existing coal plant (J.H. Miller-Alabama Power Co.) to $\$ 1,781 / \mathrm{kW}$ for a new 349-MW plant (TNP One-Texas-New Mexico Power Co.). ${ }^{2}$ Because of the absence of current market data for coal plants, NREL adopted a standard $T A G$ coal plant representation - a 300-MW pulverized coal plant with FGD sited in the Southeast.

NREL investigated potential cost improvements for advanced coal technologies. However, an examination of both EPRI and EIA cost estimates for advanced coal technologies found that these technologies offer no significant cost advantage over conventional pulverized coal technology. In fact, the projected costs of these advanced technologies would be, in most cases, significantly higher than the conventional coal plant cost adopted for the NREL analysis.

\section{Coal Price Projections}

RDI utilizes a proprietary forecast for coal prices that is some $20 \%$ below cost projections from other sources. NREL substituted the latest coal price forecast made by the Energy Information Administration (EIA), the independent statistical arm of the U.S. Department of Energy (DOE). ${ }^{3}$ Figure 1 illustrates the differences in the RDI and EIA forecasts.

\section{Coal Plant Capacity Factor}

Finally, RDI assumes an average capacity factor of $80 \%$ for its base coal plant, which is much 
higher than the actual operating experience for the nation's existing stock of coal generating plants. According to the North American Electric Reliability Council, the average capacity factor for all operating coal-fired power plants in the United States was $60 \%$ from 1990 to $1994 .^{4}$ The $T A G$ uses a $65 \%$ capacity factor as most representative of a "life-time levelized value" for new base-load power plants, including coal. ${ }^{5}$ The NREL recalculation adopts the TAG convention of a $65 \%$ capacity factor for the coal plant characterization.

When these changes are made to the RDI coal assumptions, the levelized cost of energy from the generic coal option is recalculated to be $5.36 \mathrm{c} / \mathrm{kWh}$, compared to the $3.82 \mathrm{c} / \mathrm{kWh}$ characterized in the CEED/RDI report and the $4.20 \mathrm{c} / \mathrm{kWh}$ used by RDI in its cost spreadsheet (Table 2). ${ }^{6}$ The difference in the coal cost assumptions account for $\$ 8.6$ billion of the $\$ 52$ billion CEED/RDI renewables cost estimate. The full spreadsheet recalculation is provided in Table 3 .

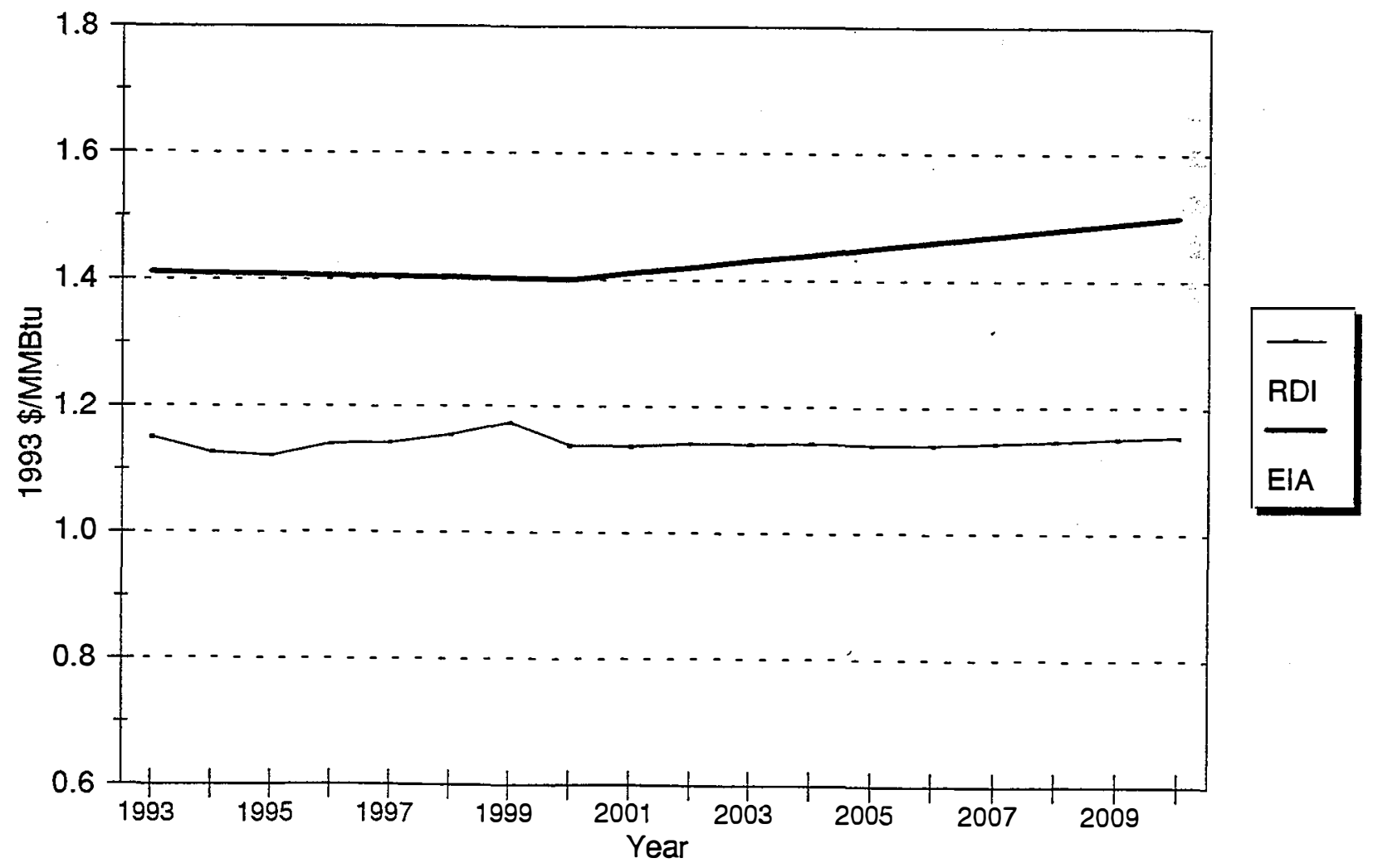

Figure 1. RDI and EIA forecasts for delivered coal prices 
NREL

Specific Technology

Region

Plant Size (MW)

Total Plant Cost $(\$ / k W)$

Average Delivered Fuel Price (\$/MMBtu)

O\&M Costs

Variable O\&M ( $₫ / k W h)$

Fixed O\&M (\$/kW-yr)

Average Annual Heat Rate (Btu/kWh)

Capacity Factor

Levelized Cost of Energy ( $(\mathbf{k} / \mathbf{k W h})$

Source
Wet FGD Subcritical/Limestone

Forced Oxidation

Northeast

Southeast

400

300

956

1,195

1.16

1.46

0.23

0.29

43.48

41.48

9550

9830

$80 \%$

$65 \%$

3.82

5.36

Duke Flour/Daniel

EPRI/TAG

RDI 


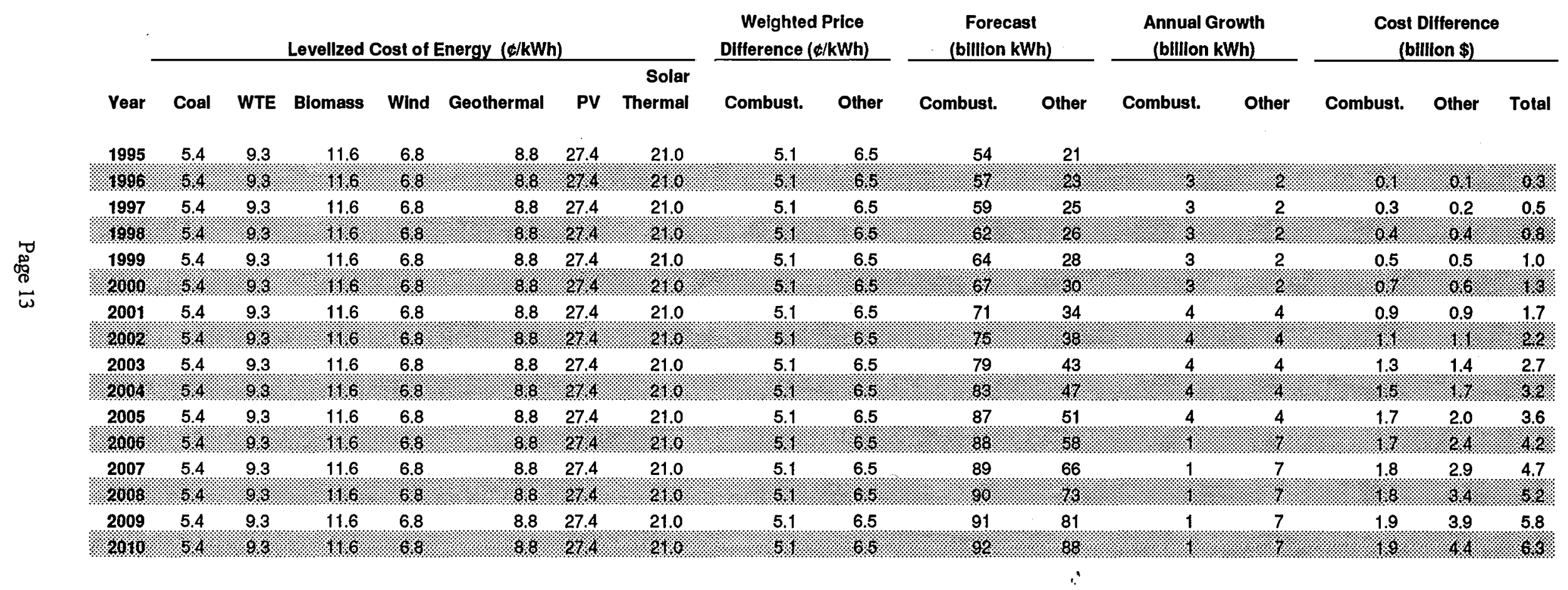

Total

Note: RDI base case with EPRI TAG coal plant cost and EIA coal price forecast. 


\section{NREL Case \#2 - Costs of Renewable Energy Technologies}

The largest difference in the RDI and NREL cost estimates is due to assumptions regarding the costs of the various renewable energy technologies. Although RDI claims to have obtained "the most current and accurate information possible" on the cost of renewable energy technologies, NREL found that this was not the case. While RDI postulates a cost range of $6.8 \mathrm{c} / \mathrm{kWh}$ to $27.4 \mathrm{c} / \mathrm{kWh}$ for various renewables, the results of several recent utility competitive bidding solicitations show that many different types of renewables projects have been offered in a price range of $4.5 \mathrm{c} / \mathrm{kWh}$ to $6.0 \mathrm{c} / \mathrm{kWh} .^{7}$ In June 1995 , Northern States Power announced a winning levelized bid price of $3.0 \mathrm{c} / \mathrm{kWh}$ for development of a $100-\mathrm{MW}$ wind project. ${ }^{8}$ Furthermore, RDI assumes no future improvements in renewable energy costs from the high assumed values.

In this analysis, NREL used renewable technology costs prepared by the DOE renewable energy technology programs. ${ }^{9}$ The DOE costs incorporate expected technology and cost improvements through the year 2010. Table 4 compares the DOE and RDI renewable technology cost figures. We reiterate here that no cost improvements were assumed for coal-fired generation because both EPRI and EIA generally project higher costs from advanced coal technologies.

When the more realistic renewable energy costs and projected cost improvements are combined with the adjusted costs for future coal generation, the CEED/RDI renewables cost estimate is reduced by another $\$ 31.6$ billion. Table 5 provides the recalculation results for this case. 
RDI Assumptions (1993 \&/kWh)

Wind

1995

2000

2005

2010

Geothermal

$\begin{array}{ll} & 2000 \\ & 2005 \\ & 2010 \\ & \\ \text { Biomass } & 1995 \\ & 2000 \\ & 2005 \\ & 2010 \\ & \\ \text { PV } & 1995 \\ & 2000 \\ & 2005 \\ & 2010 \\ & 1995 \\ \text { Solar Thermal } & 2000 \\ & 2005 \\ & 2010 \\ & \\ & 1995 \\ & 2000 \\ & 2005 \\ & 2010\end{array}$

6.8

6.8

6.8

6.8

8.8

8.8

8.8

8.8

11.6

11.6

11.6

11.6

27.4

27.4

27.4

27.4

21.0

21.0

21.0

21.0

9.3

9.3

9.3

9.3
DOE Projections

(1993 c/kWh)

5.3

4.1

3.9

3.5

5.2

4.0

3.8

3.7

8.5

8.1

7.5

7.2

21.8

16.4

13.1

8.7

10.5

8.6

8.1

8.1

8.2

8.2

8.2

8.2 
Table 5. NREL Case \#2 Recalculations'

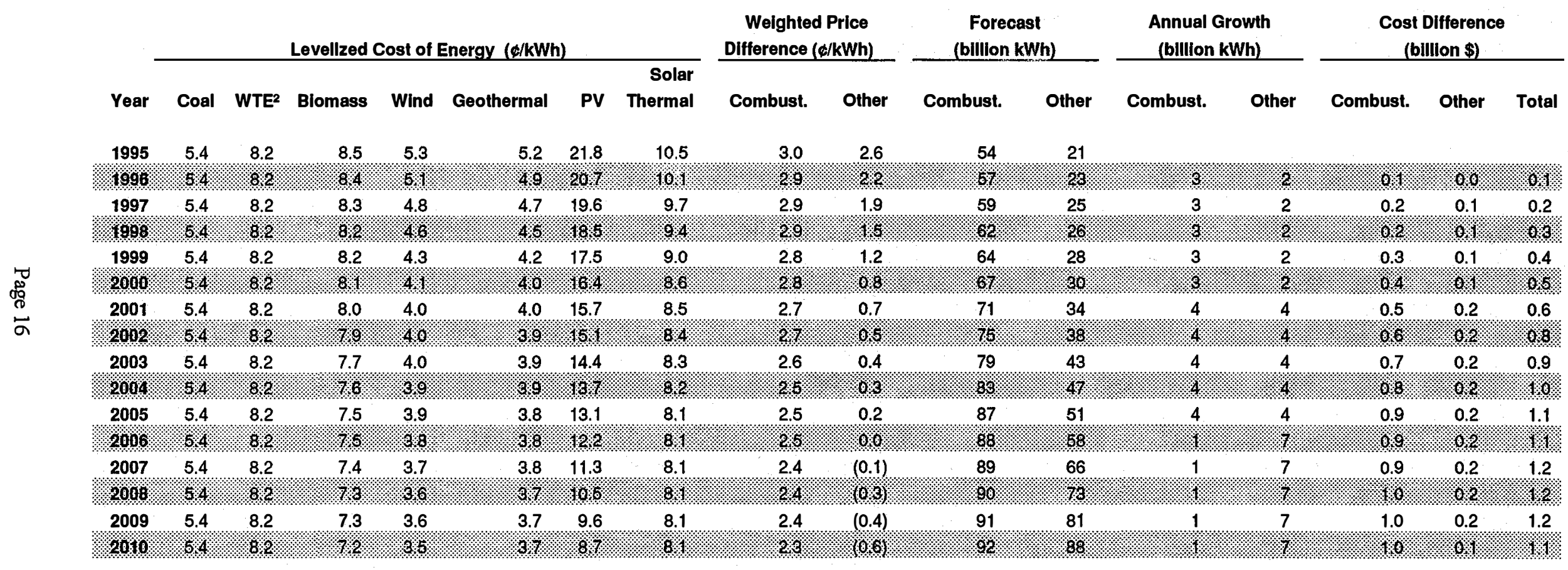

Total:

Notes: 1. RDI base case scenario with EPRI TAG coal plant cost, EIA coal price forecast, and DOE levelized cost projections for renewables.

2. No DOE estimates for WTE. EPRI TAG and RDI numbers were used. 


\section{NREL Case \#3 - Market Penetration of Renewable Energy Technologies}

The final calculation sensitivity relates to the market penetration rate of the different renewable energy technologies. It is reasonable to assume that those technologies that are economically competitive will penetrate the market faster than those that are only marginally cost effective. Also, there are initial limitations on how quickly an industry can gear up to supply its product.

Keeping this in mind, NREL substituted more orderly technology penetration scenarios for the fixed market share approach used by RDI (Tables 6 and 7). The NREL penetration assumptions also more closely resemble the current energy and capacity contributions from renewable power sources. Within the combustion-oriented renewable energy group, NREL changed the ratio of biomass to WTE; NREL used 75/25 instead of RDI's 50/50. Within the "naturally occurring" group, contributions from geothermal, wind, solar thermal, and photovoltaics (PV) more closely follow the EIA-adopted forecast for individual renewable technologies; RDI used a fixed 37.5/37.5/12.5/12.5 market share ratio. ${ }^{10}$

The change in market penetration assumptions, when combined with the coal and renewable cost adjustments, yields a further reduction of $\$ 9.9$ billion from the CEED/RDI $\$ 52$ billion renewables cost estimate (Table 8). This leaves a total cost estimate of $\$ 1.9$ billion over 15 years to achieve a doubling in the contribution of nonhydro renewable energy sources to the nation's electricity supply mix. 


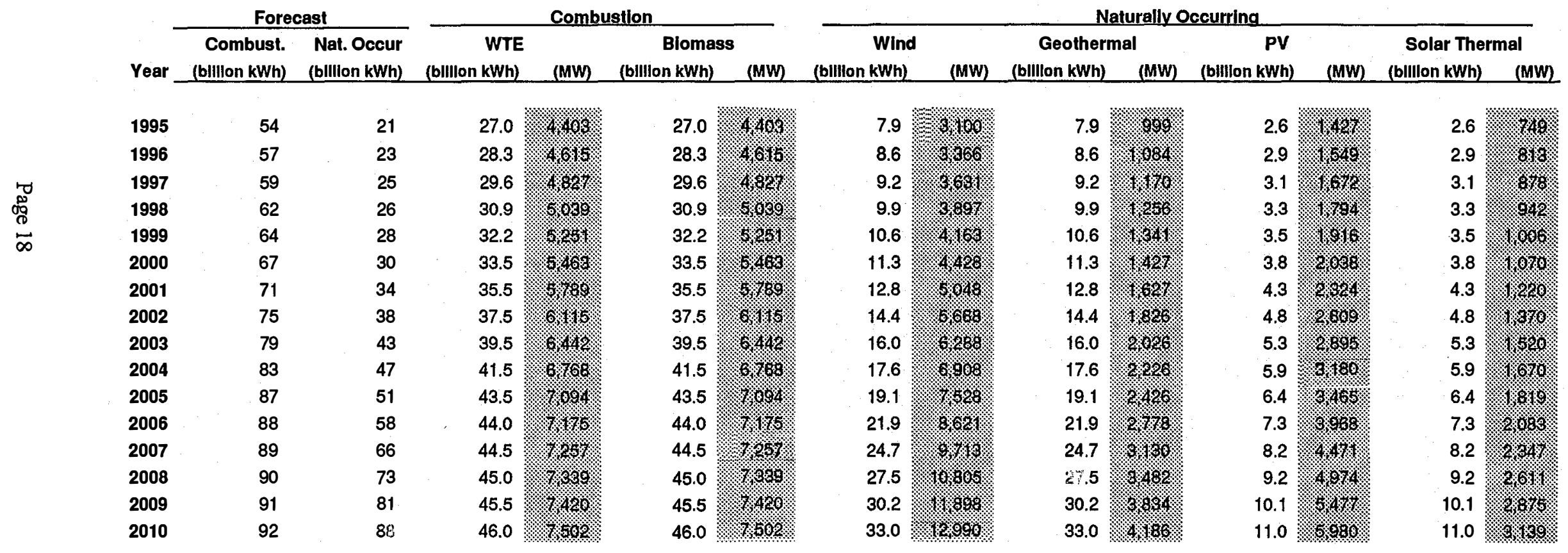




\section{Table 7. NREL's Alternative Renewable Energy Growth Scenario}

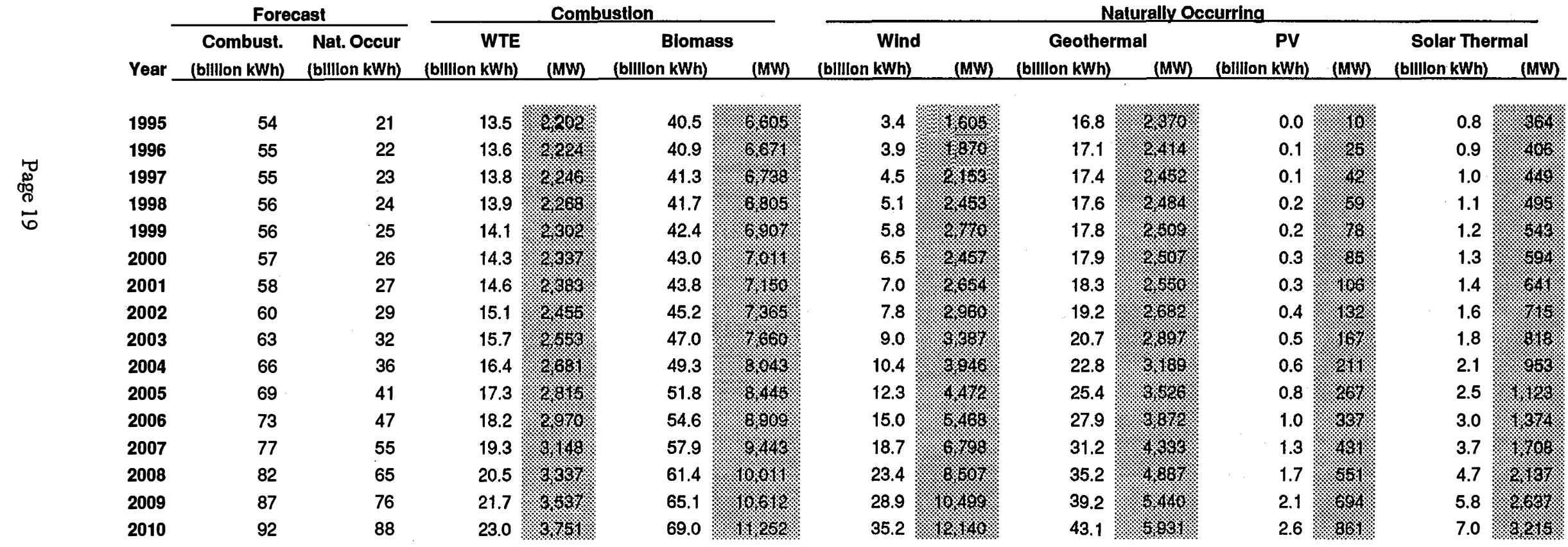




\section{Table 8. NREL Case $\$ 3$ Recalculations}

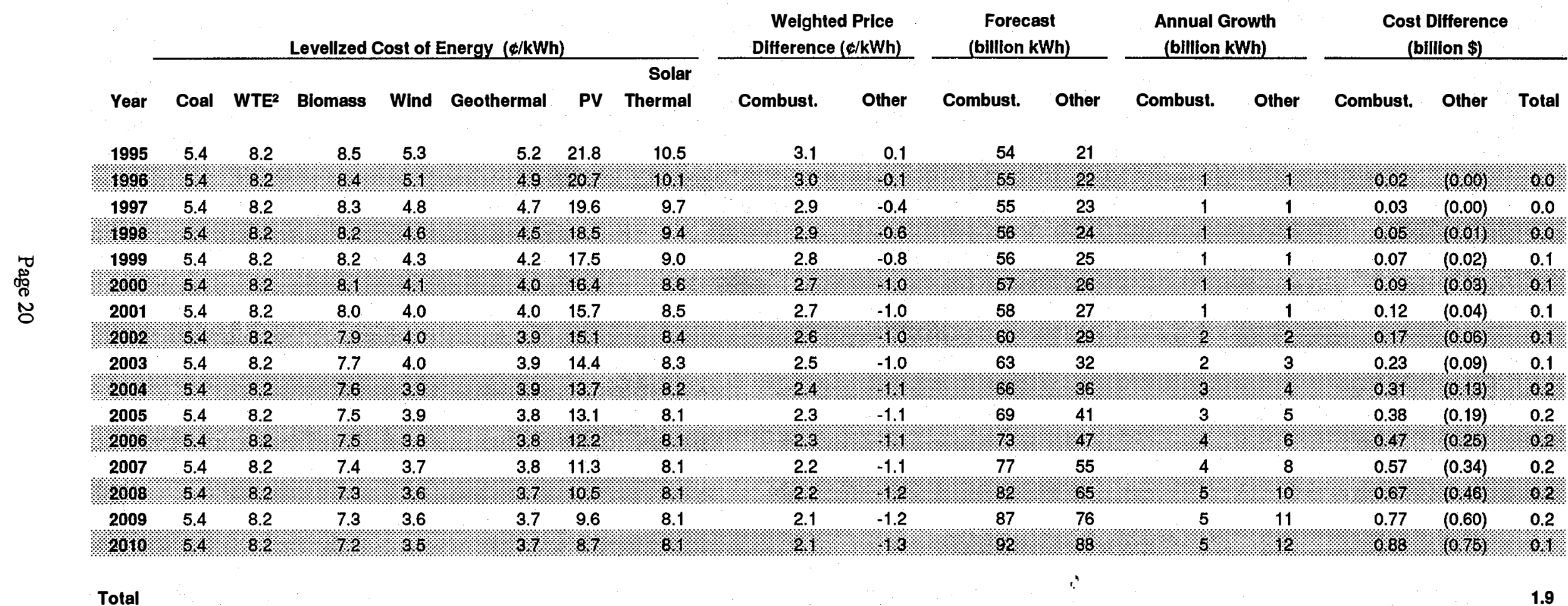

Note: NREL's alternative renewable energy growth scenario with EPRI TAG coal plant cost, EIA coal price forecast, and DOE levelized cost projections for renewables 


\section{Endnotes}

1. See Electric Power Research Institute, $T A G^{T M}$ Technical Assessment Guide: Electricity Supply - 1993, EPRI TR-102276-V1R7, Volume 1: Rev. 7, June 1993.

2. Also in 1991, Cincinnati Gas and Electric Company brought its Zimmer plant (1426 MW) on line at a cost of $\$ 2,286 / \mathrm{kW}$. However, the Zimmer plant was a nuclear-to-coal plant conversion and thus is not reflective of coal-only construction costs.

3. U.S. Energy Information Administration, Annual Energy Outlook 1995 with Projections to 2010, DOE/EIA-0383(95), January 1995.

4. North American Electric Reliability Council, Generating Unit Statistics 1990-1994, June 1995.

5. Electric Power Research Institute, Op Cit, p. 2-2.

6. Additional differences can be noted in the O\&M cost and heat rate assumptions.

7. These include bidding solicitations conducted by New England Power, Portland General Electric, and the three California investor-owned utilities.

8. The wind energy bid price accounts for the net impact of the federal production tax credit and a state property tax levy. National Renewable Energy Laboratory, State Renewable Energy News, Summer 1995.

9. U.S. Department of Energy, Office of Utility Technologies, Renewable Energy Technology Characterizations, 1994. The one exception is WTE technology for which DOE cost estimates were not available; NREL used WTE plant cost data from the TAG and RDI's waste fuel cost data.

10. U.S. Energy Information Administration, $O p$ Cit. 


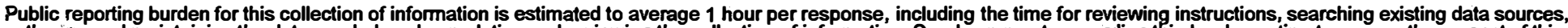

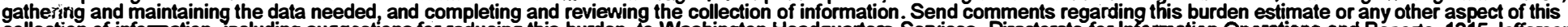

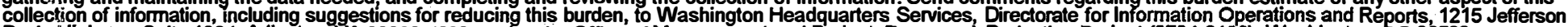

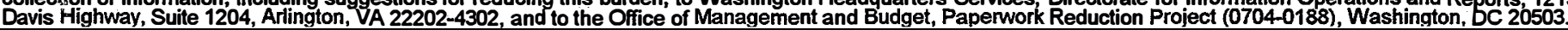
1. AGENCY USE ONLY (Leave blank)
2. REPORT DATE
October 1995
3. REPORT TYPE AND DATES COVERED
technical report

4. TITLE AND SUBTITLE

The True Cost of Renewables: An Analytic Response to the Coal Industry

5. FUNDING NUMBERS

AS819409

6. AUTHOR(S)

B. Swezey and Y. Wan

7. PERFORMING ORGANIZATION NAME(S) AND ADDRESS(ES)

National Renewable Energy Laboratory

1617 Cole Boulevard

Golden, Colorado 80401-3393

8. PERFORMING ORGANIZATION REPORT NUMBER

TP-462-200032

U.S. Department of Energy

1000 Independence Ave., SW

10. SPONSORING/MONITORING AGENCY REPORT NUMBER

Washington, DC 20585

11. SUPPLEMENTARY NOTES

DE95013114

12a. DISTRIBUTION/AVAILABILITY STATEMENT

National Technical Information Service

12b. DISTRIBUTION CODE

U.S. Department of Commerce

UC 1320

5285 Port Royal Road

Springfield, VA 22161

13. ABSTRACT (Maximum 200 words)

This report is an analysis of a coal industry study critical of renewable energy. The National Renewable Energy Laboratory (NREL) was commissioned by the U.S. Department of Energy to review the assumptions in the coal report entitled, Energy Choices in a Competitive Era: The Role of Renewable and Tradiuional Energy Resources in America's Electric Generation Mix, prepared by Resource Data International, Inc. (RDI) for the Center for Energy and Economic Development (CEED), an umbrella organization of pro-coal interests. The NREL analysis finds that the conclusions in the CEED/RDI study are based on faulty data and assumptions regarding the comparative economixs of coa? and renewable energy development. After correcting the errors, NREL finds that a modest growth path of renewable resource development would cost the nation little more than the projected electricity market cost for fossil-fuel-based power generation, even before considering the environmental benefits that would accompany this development.

14. SUBJECT TERMS
renewable energy cost; coal industry; renewable energy technologies

15. NUMBER OF PAGES

26

16. PRICE CODE

17. SECURITY CLASSIFICATION OF REPORT unclassified
18. SECURITY CLASSIFICATION OF THIS PAGE unclassified
19. SECURITY CLASSIFICATION OF ABSTRACT unclassified
20. LIMITATION OF ABSTRACT UL

NSN 7540-01-280-5500

Standard Form 298 (Rev. 2-89) Prescribed by ANSI Std. Z39-1 